11. Гриценко, Е.В. Понятие и цели межмуниципального сотрудничества / Е.В. Гриценко // Консультационная служба. 2006. № 2. С. 34-40.

12. Кожевников, О.А., Проблемы законодательного регулирования организационных форм межмуниципального сотрудничества в Российской Федерации / О.А. Кожевников // «Государственная власть и местное самоуправление». 2006. № 5. С. 23-28.

13. Маркварт, Э. Межмуниципальное сотрудничество в хозяйственной сфере /Э. Маркварт // Настольная книга для муниципальных политиков / Под ред. Е. С. Шургиной, В. А. Савицкого. М., 2009. C. 266.

14. Муниципальное право России: учебник для бакалавров / А.Н. Кокотов [и др.]; под.ред. А.Н. Кокотова [и др.]. 3-е изд., перераб. и доп. М.: Издательство Юрайт, 2013. 559 с.

15. Петроградская, А.А. Муниципальное сотрудничество: к вопросу об определении дефиниции / А.А. Петроградская // Административное и муниципальное право. 2011. № 2, С. 34 - 37.

16. Петроградская, А.А. Виды и формы межмуниципального сотрудничества в Российской Федерации / А.А. Петроградская // Вестник СамГУ. 2010. №5 (79). С. 256-262.

17. Постовой, Н.В. Муниципальное право России: учебник / Н.В. Постовой, В.В. Таболин, Н.Н. Черногор, 4-е изд., перераб. и доп. М.: Юриспруденция, 2016. 456 с.

18. Рагозина Л. Правовое обеспечение и практика осуществления различных форм межмуниципальной кооперации в России и за рубежом. М.: Институт экономики города, 2009. С. 74-79.

19. Об утверждении Соглашения о сотрудничестве между муниципальными образованиями «Город Псков» Псковской области, Российская Федерация, волости ВярскаПылваского уезда и волости МеремяеВырусского уезда Эстонской Республики: Решение Псковской городской Думы от 29.06.2010 г. № 1323 [Электронный ресурс] Режим доступа: http: // www.consultant.ru.

20. Комитет Государственной Думы по федеративному устройству и вопросам местного самоуправления. [Электронный ресурс] Режим доступа: http://www.komitet4.km.duma.gov.ru/Soyuzy-i-associacii-municipalnyh-obrazov

\title{
Хороших А.Э. \\ Сравнительный анализ классификации юридических лиц России и Соединенных Штатов Америки
}

Уральский государственный юридический университет (Россия, Екатеринбург)

doi:10.18411/spc-20-03-2018-10

idsp: 000001:spc-20-03-2018-10

Начну с того, что в США, в отличие от Российской Федерации, четкой классификации юридических лиц законодательством не установлено. При этом каждый штат вправе самостоятельно устанавливать в каких организационно-правовых формах возможно ведение деятельности на его территории. Проанализировав законодательство ряда штатов, я пришла к выводу, что в целом юридические лица можно разделить на публично-правовые образования, которые создают корпорации для осуществления контрольно-надзорных функций в той или иной области, и прочие юридические лица. В свою очередь к последним относятся партнерство (простое и коммандитное), общество с ограниченной ответственностью, траст (доверительная собственность), корпорации (корпорация типа «С» и корпорация типа « $\mathrm{S} »)$, иностранные неинкорпорирванные объединения и другие.

Также, как и в нашем отечественном праве, в американской системе права юридические лица можно классифицировать на коммерческие и некоммерческие. Безусловно, на первый взгляд данный подход схож с позицией российского законодателя. Однако следует отметить, что законодательство штатов, «...выделяя определенные организационно-правовые формы юридических лиц, которые используются для ведения некоммерческой деятельности, либо запрещает любую деятельность, приносящую доход для юридических лиц, созданных в этих формах, либо, не вводя общего запрета, устанавливает строгие профессиональные, финансовые требования для ведения того или иного вида предпринимательской деятельности, которым трудно соответствовать. Более того, законы большинства штатов ограничивают коммерческую деятельность некоммерческих юридических лиц целями создания. Иными словами, многие некоммерческие юридические лица вправе 
заниматься только той предпринимательской деятельностью, которая соответствует их основной уставной». [1, с. 264]

Кроме того, существует и иная классификация юридических лиц в зависимости от того, является ли извлечение прибыли их основной деятельностью или же нет. В связи с этим огромный интерес представляет такая организационно-правовая форма, как корпорация, которая является самостоятельным лицом и независимым от его учредителей. Как правило, все корпорации обладают общей правоспособностью. Однако в каждом штате законодатель устанавливает ограничения по сферам и видам деятельности. Так, например, в Нью-Йорке корпорация вправе вести любой вид деятельности, за исключением банковской, страховой, связанной с железнодорожными перевозками и по управлению имуществом в качестве доверительного собственника/управляющего [3]. Также существуют профессиональные корпорации, которые могут осуществлять лишь один вид деятельности. Таким образом корпорации в каждом отдельном штате наделяются специальной правоспособностью.

При этом, важно отметить, что некоммерческие корпорации более разнообразны по своей форме. К первой группе можно отнести корпорации, действующие в публичных интересах (nonprofitpublicbenefitcorporation). Основная цель таких корпораций оказание услуг, например, коммунально-бытовых. Во вторую группу входят корпорации так называемого взаимного интереса, направленные на возмездное оказание услуг. К третьей группе можно отнести религиозные некоммерческие корпорации, некоммерческие корпорации со специальными целями.

Говоря о некоммерческих организациях, необходимо также упомянуть об общественных организациях на федеральном уровне. Для создания такой организации требуется принятие специального закона о деятельности такой организации. Однако законы некоторых штатов предусматривают ведение общественно-полезной деятельности без образования юридического лица, например, различные общественные движения, фонды. Данная ситуация аналогична с российским законодательством. В соответствии со статьей 3 Федерального закона «Об общественных объединениях» от 19 мая 1995 года № 82-Ф3 Закона «Об общественных объединениях» [2], создаваемые гражданами общественные объединения могут регистрироваться в порядке, предусмотренном настоящим Федеральным законом, и приобретать права юридического лица либо функционировать без государственной регистрации и приобретения прав юридического лица.

В Соединенных Штатах деятельность общественных объединений регулируется главой 36 Свода законов США [4]. Данный акт классификации не предоставляет, а лишь перечисляет формы общественных объединений.

Таким образом, классификации видов организационно-правовых форм юридических лиц США и РФ присущи как сходства, так и различия. Однако в России виды юридических лиц более систематизированы и их основная классификация установлена на законодательном уровне.

$$
* * *
$$

1. Семилютина Н.Г. «Юридические лица в гражданском праве зарубежных стран: Монография», «ИЗиСП», «ИНФРА-М», 2015. 264 с.

2. Федеральный закон от 19.05.1995 № 82-Ф3 (ред. от 20.12.2017) «Об общественных объединениях». СПС «КонсультантПлюс».

3. New York Department of State's Division of Corporations, State Records and Uniform Commercial Code. URL: https://www.dos.ny.gov/corps/index.html (дата обращения: 15 марта 2018 года)

4. United States Code. Office of the Law Revision Counsel of the United States House of Representatives. URL: http://uscode.house.gov/browse/prelim@title/ chapter36\&edition=prelim (дата обращения: 16 марта 2018 года). 